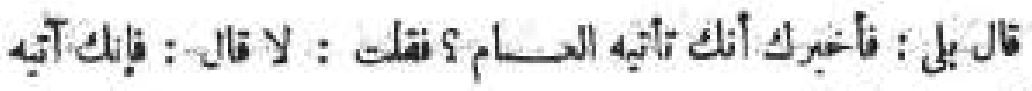

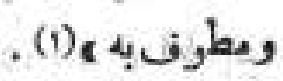

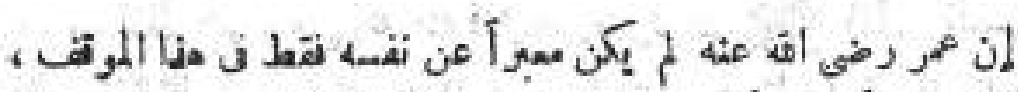

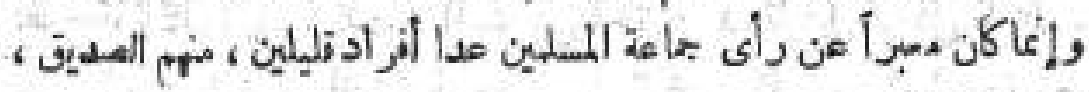
رضى الته عث4.

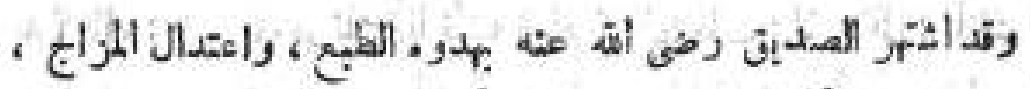

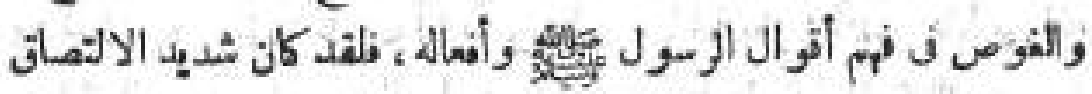

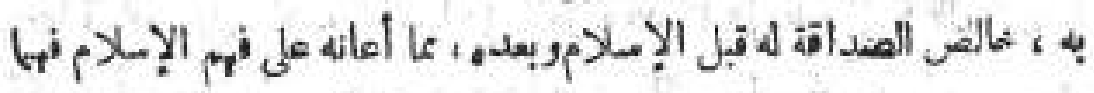

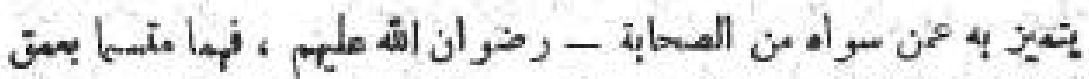

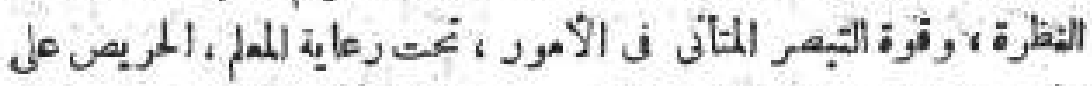

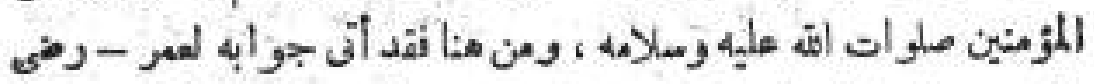

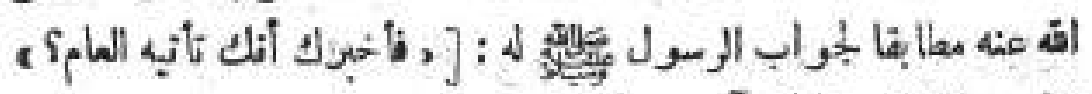

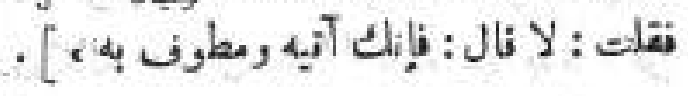

ولا بقلح هذا في عر رضى الته عثه اللىى الشته بعدة الذكا.، وحدة

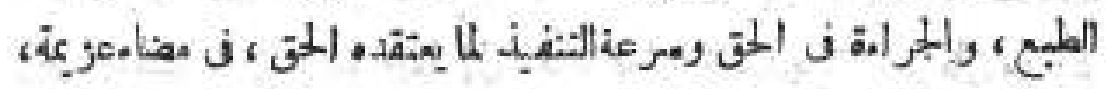

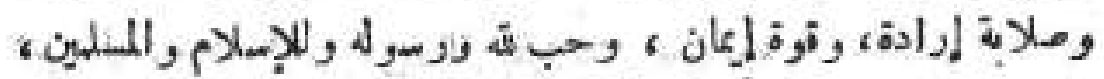

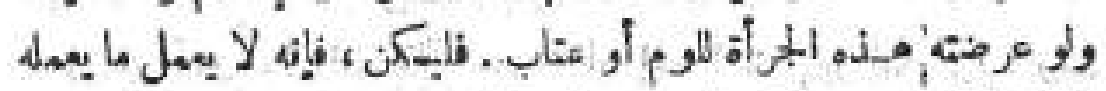

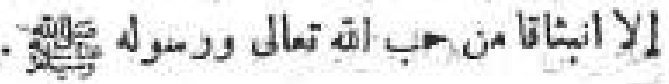

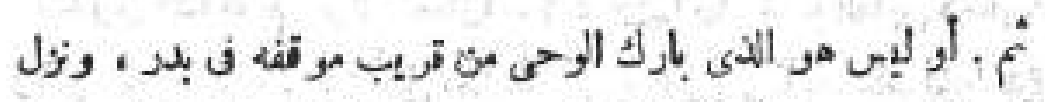

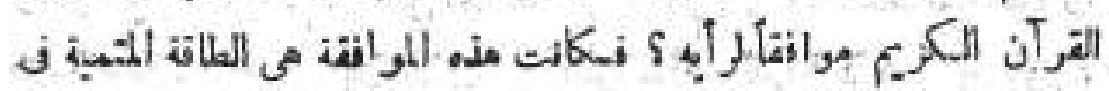




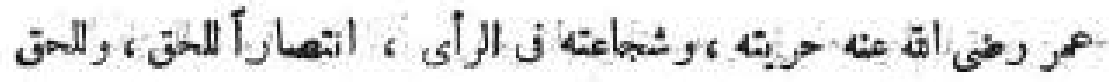
.

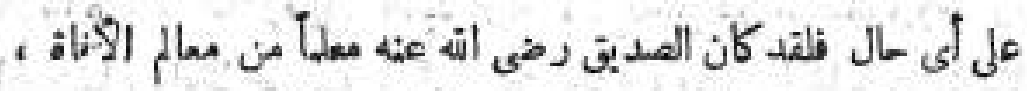

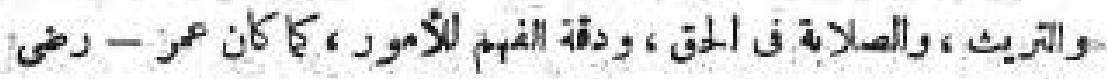

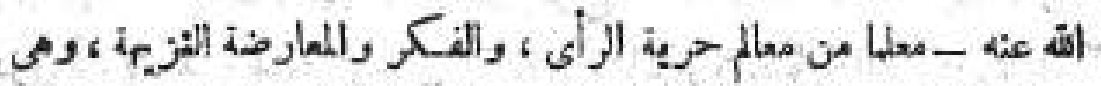

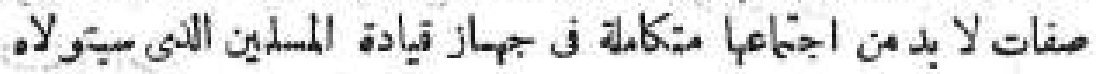

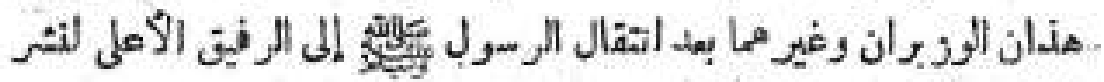

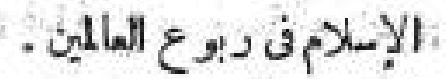

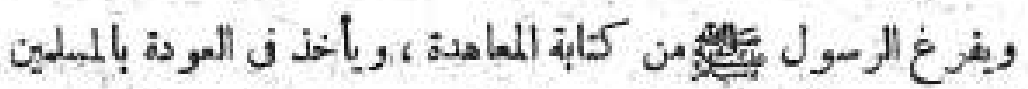

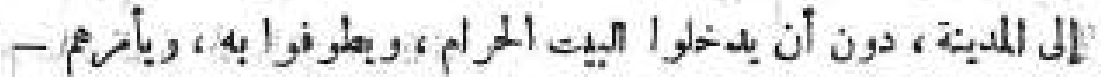

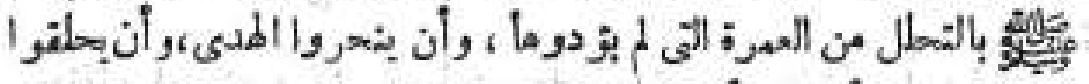

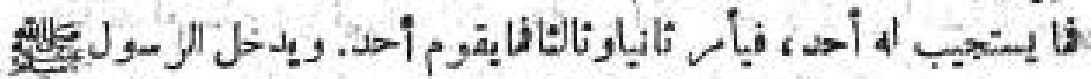

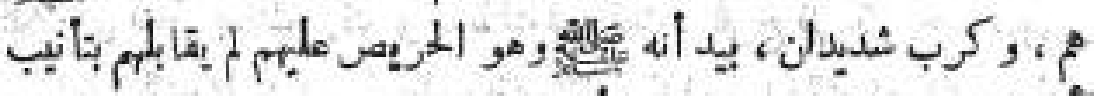

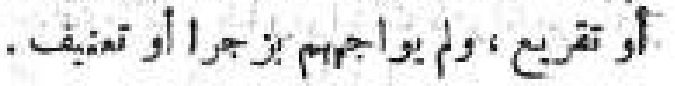

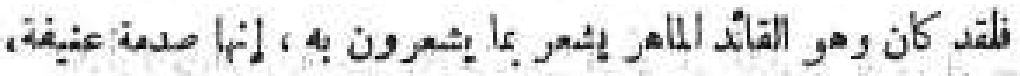

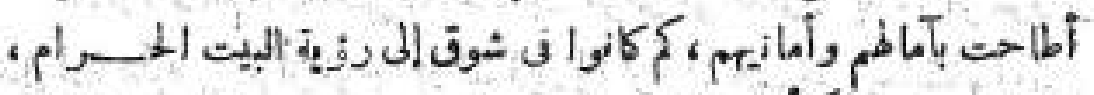

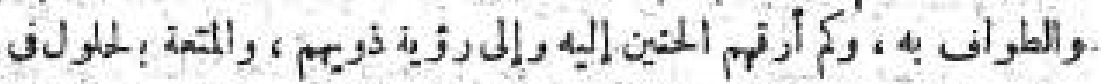

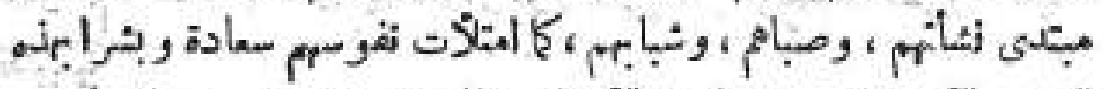

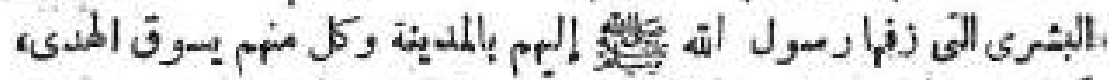

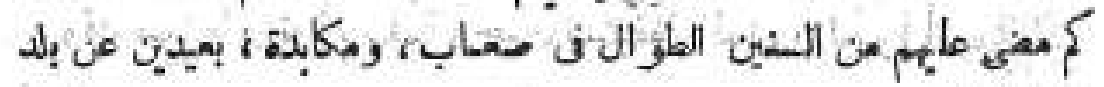
الماند الحرام

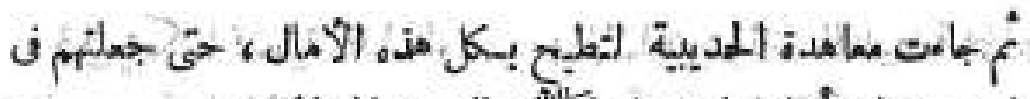

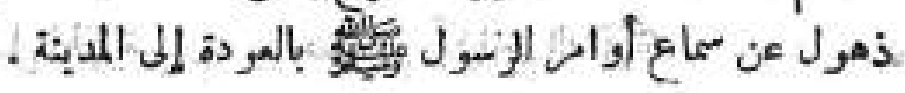




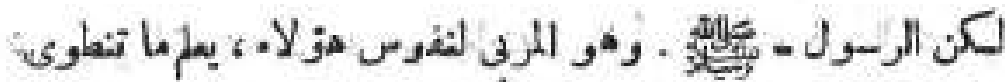

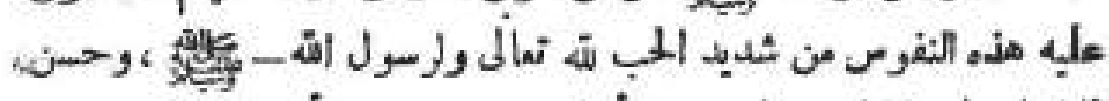

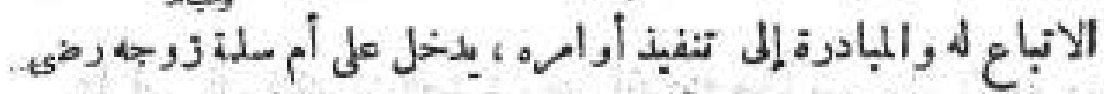

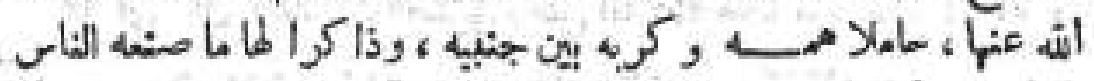

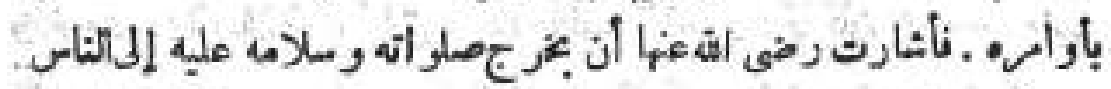

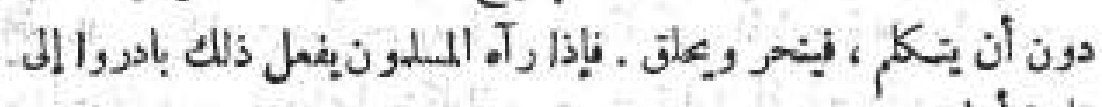
تليتية أوامره.

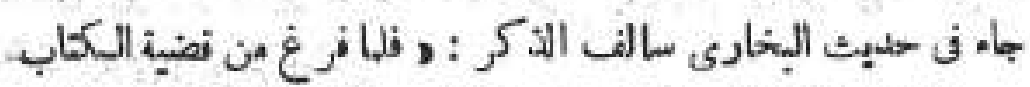

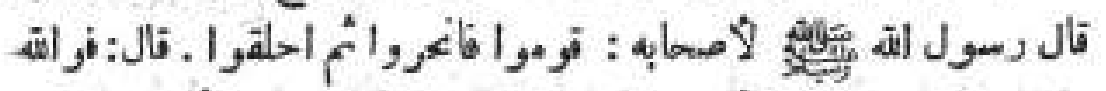

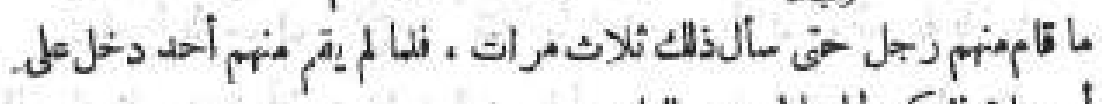

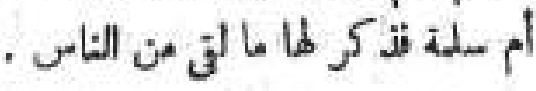

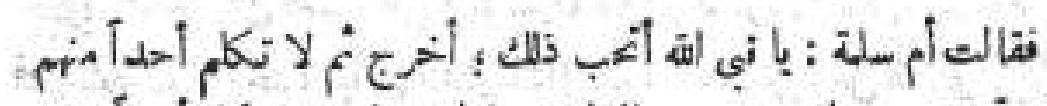

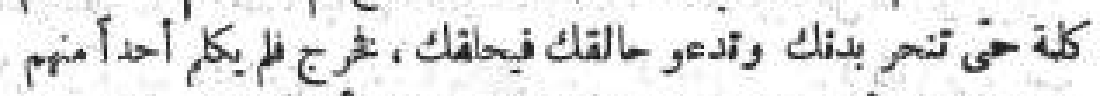

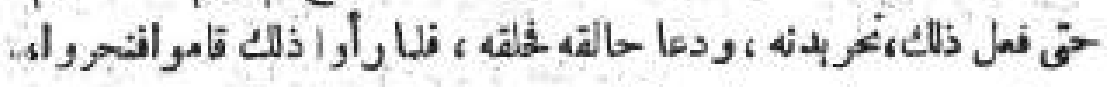

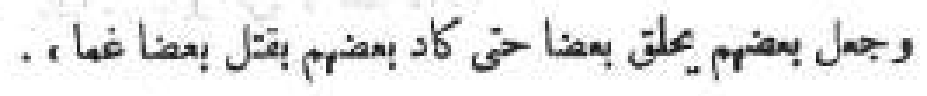

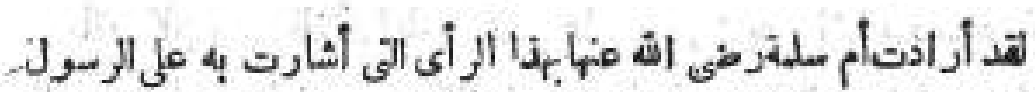

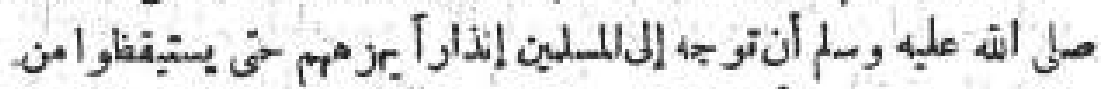

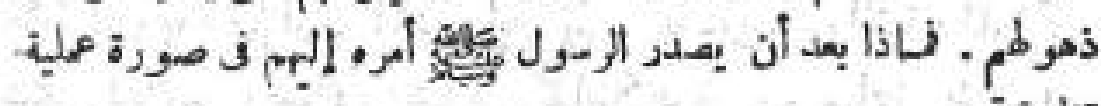

تطبيفية .

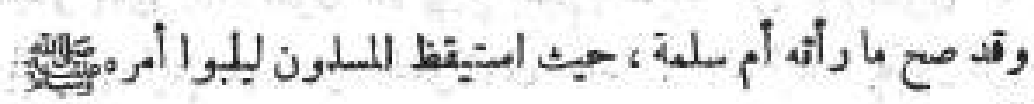
على الفور .

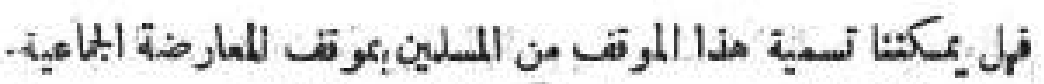

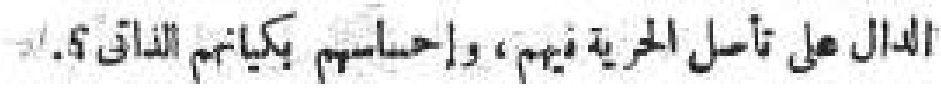


هو كذالك ، وسواء كان المسلهون هـا معذوربن ، أو غير معذورين

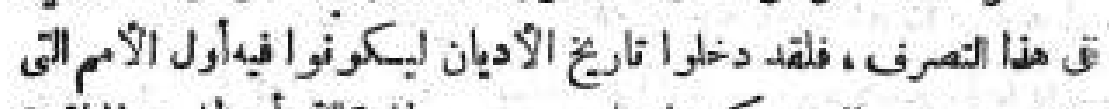

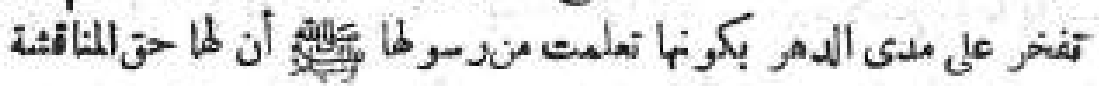

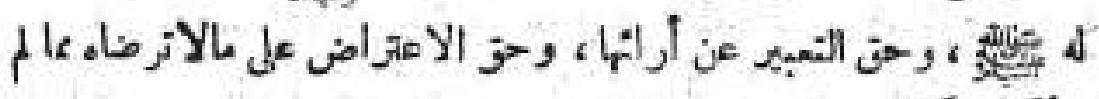
. دئ

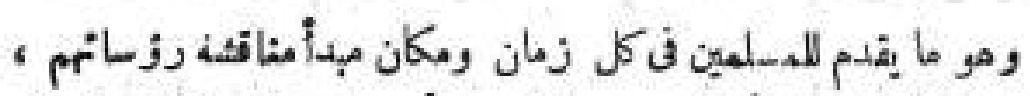

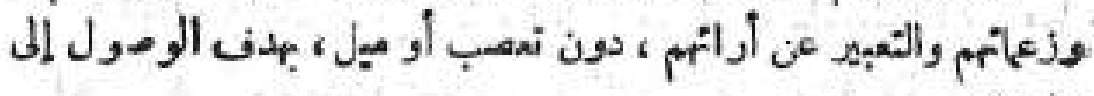
(1) 1 (1)

\section{: - مابة الإسلامبحرية المبلم}

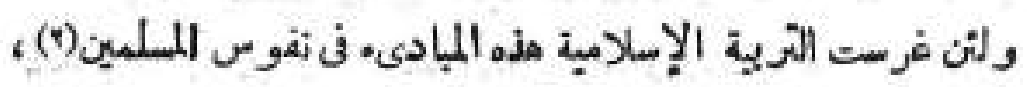

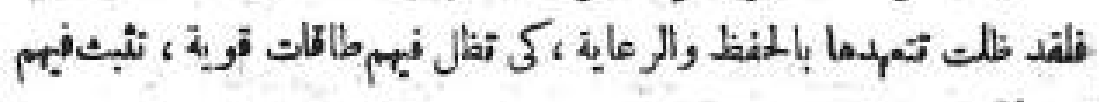

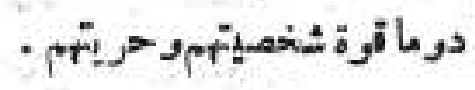

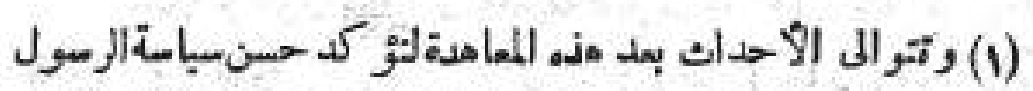

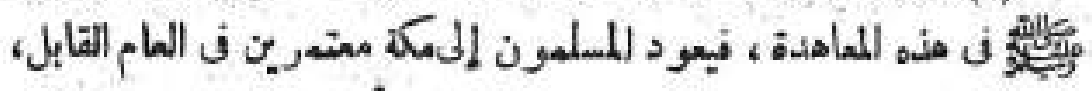

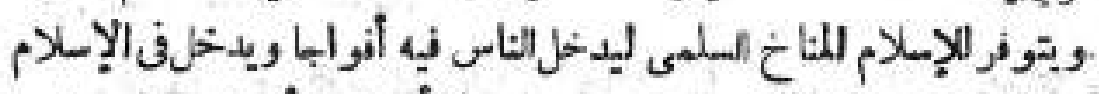

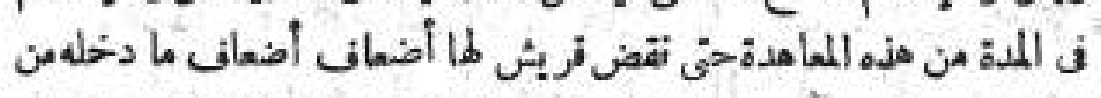

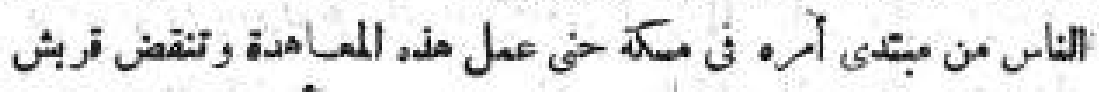

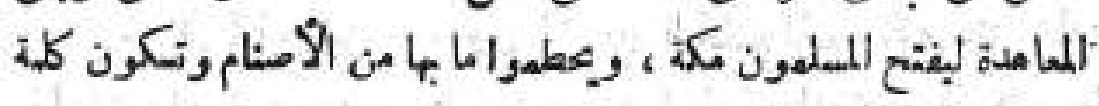

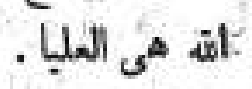

. (r) زابع الجزه. الأول المدد السادس لحولية المكلية. 


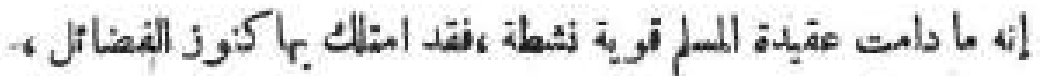

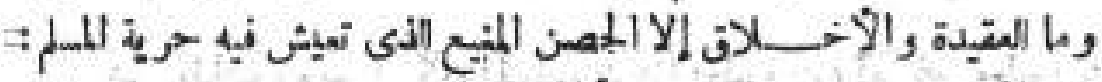

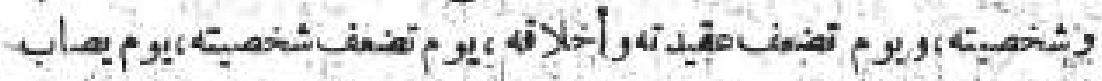

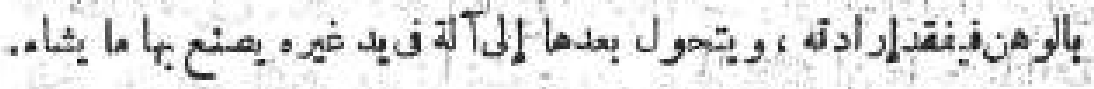

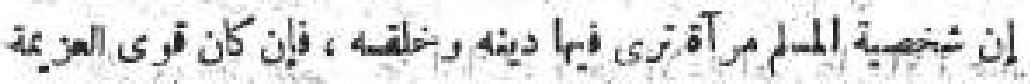

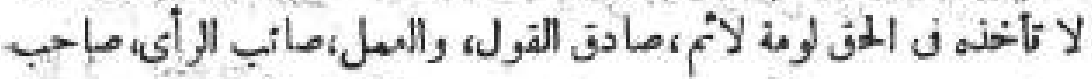

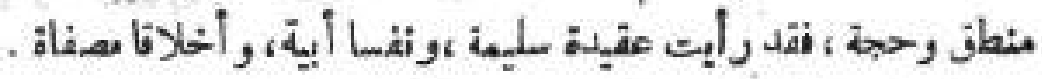

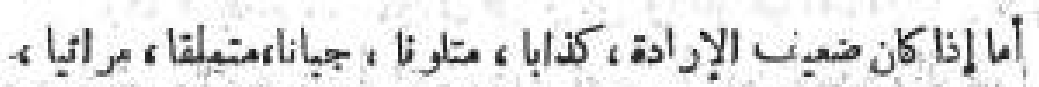

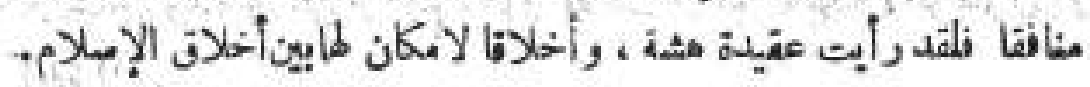

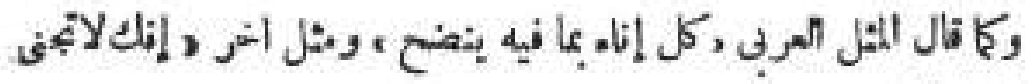
من الشوك المنب ، الم المرب

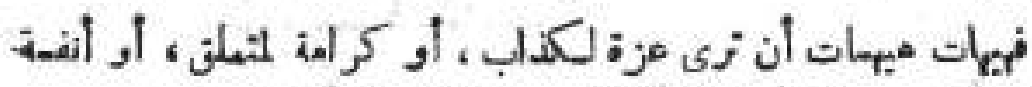

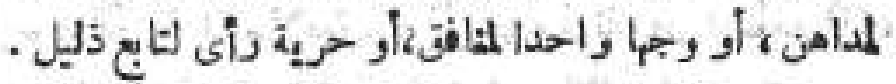

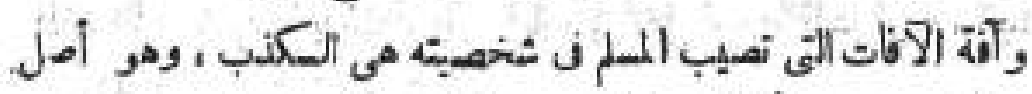
الفجور كله ، وسبب أمر اض القلوب من نفاق ورياه، وبجنين .

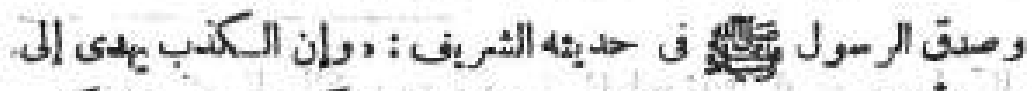

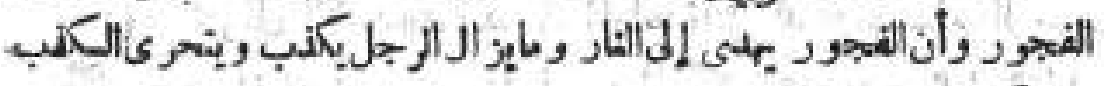

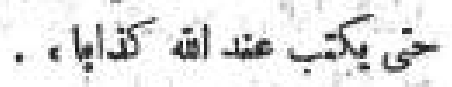

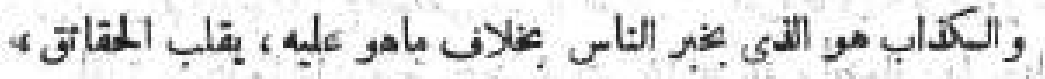

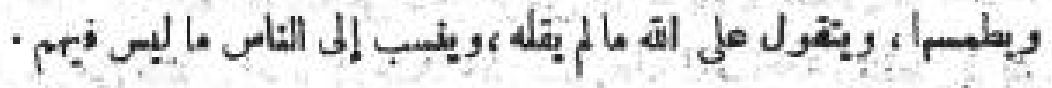

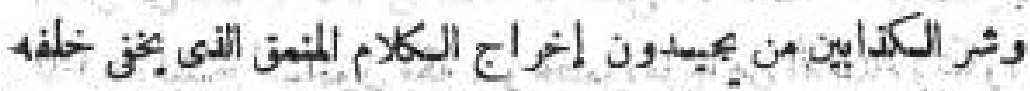

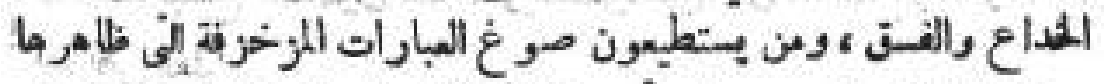

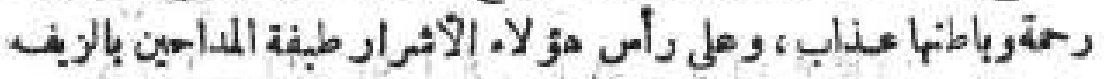
والهبكان . 


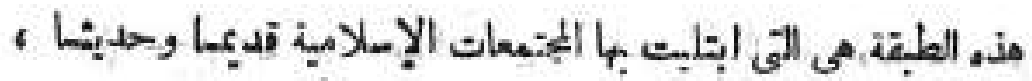

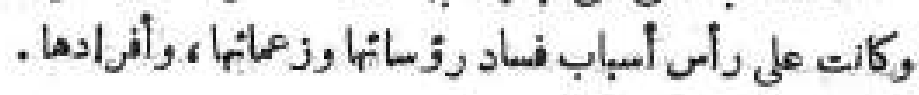

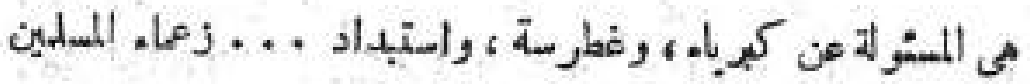

$$
\text { وقادن }
$$

مى المزلزلة لـكيان الإرادات الحرة ، والمقرضة لاستغلال الأفراد

$$
\text { ,.... }
$$

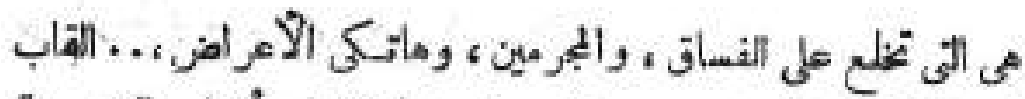

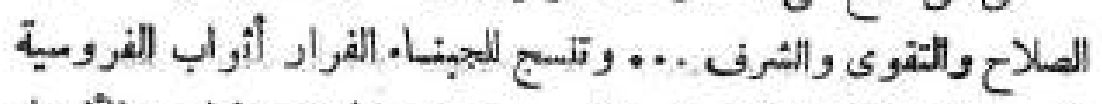

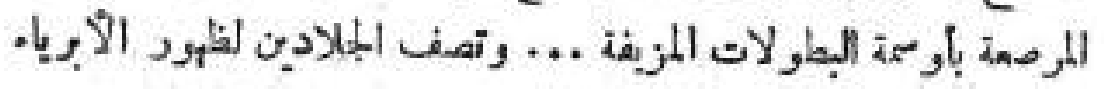

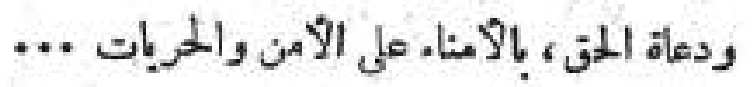

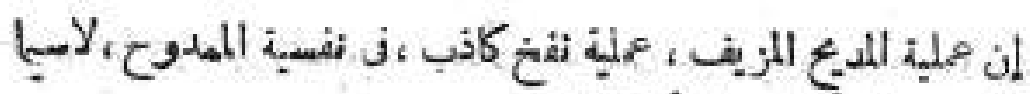

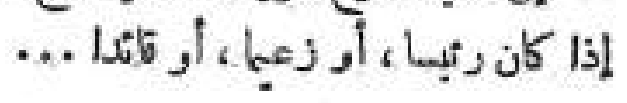

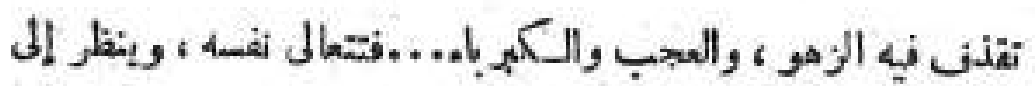

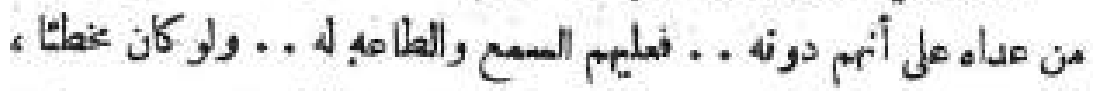

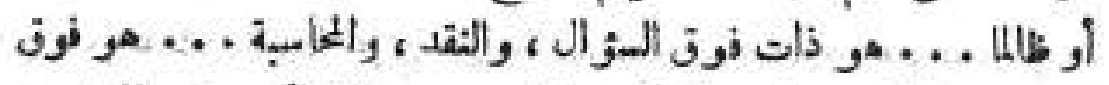

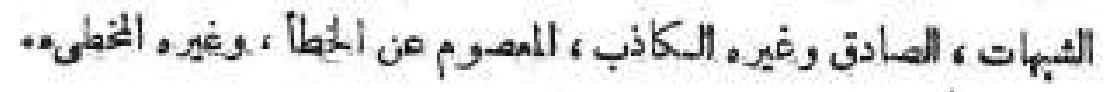

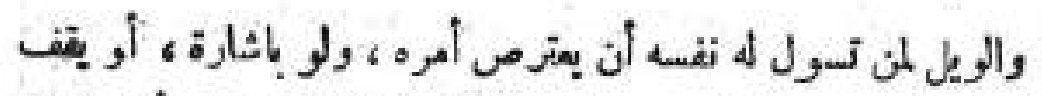

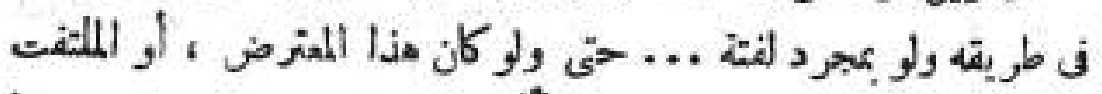

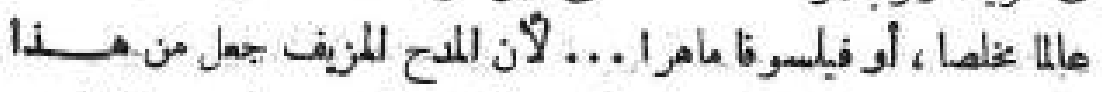

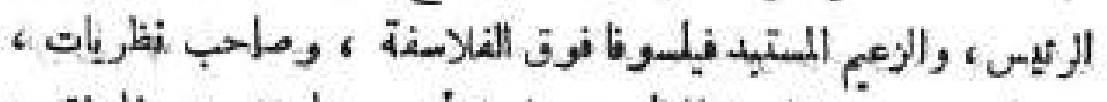

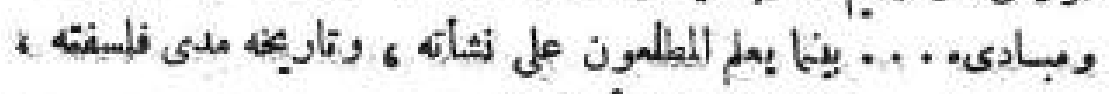

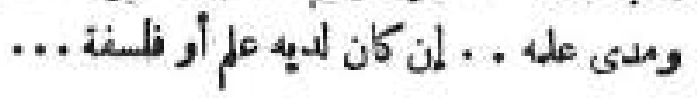




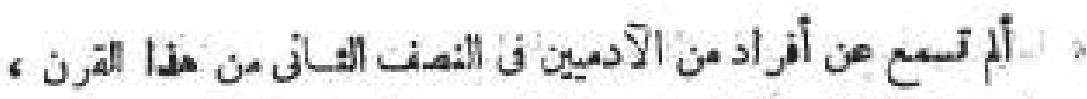

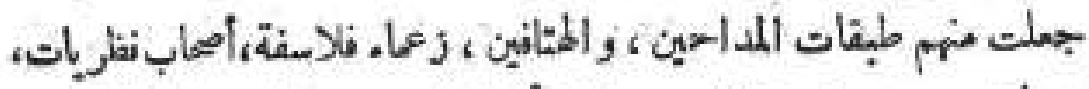

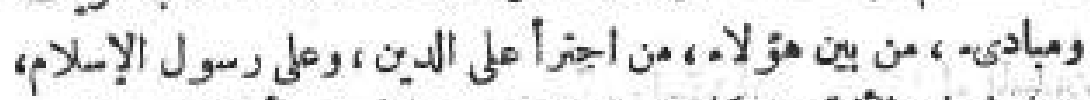

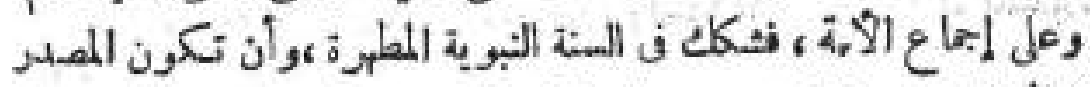

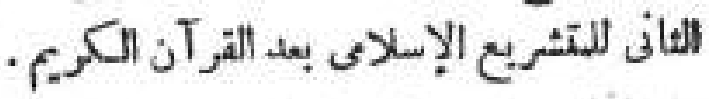

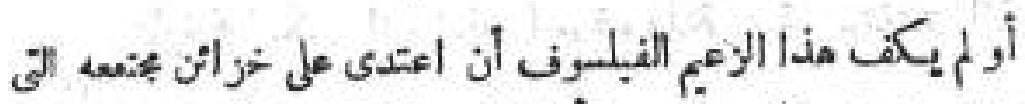

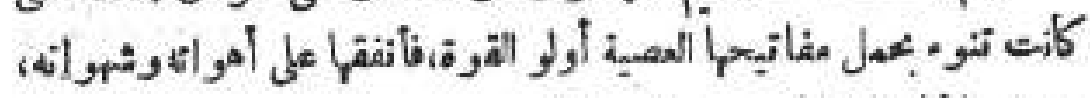

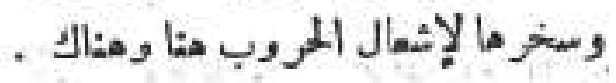

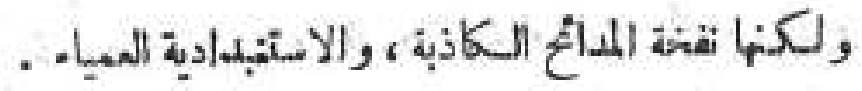

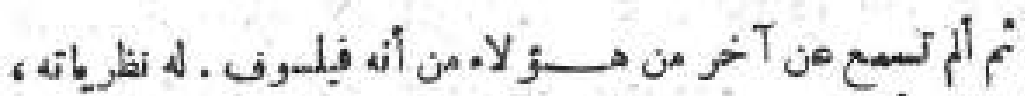

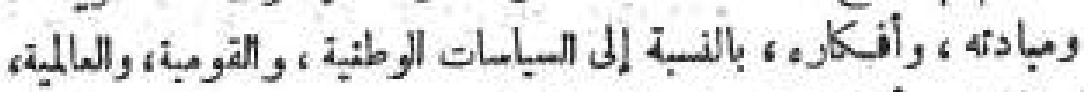

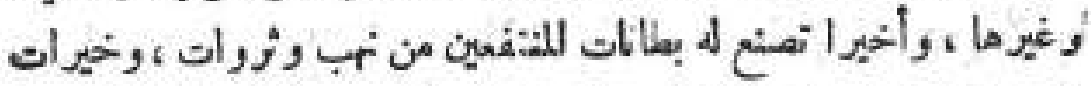

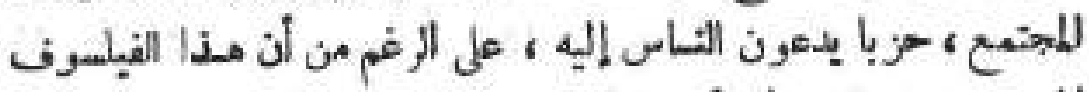

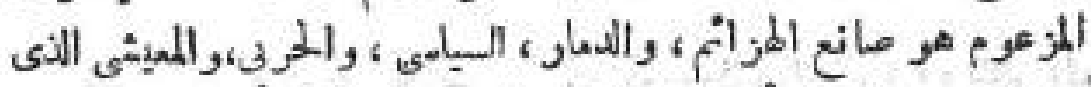

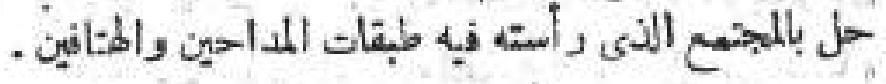

وحلث هيا ولا خخرج عن هذا المجتمع الذى قبر فيه هذا اللفيلسوف

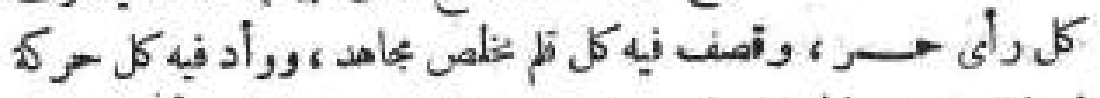

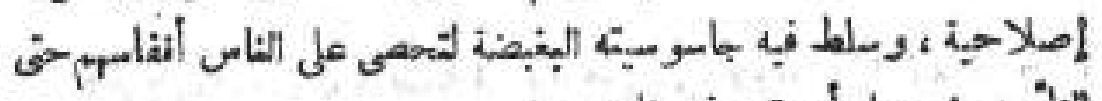

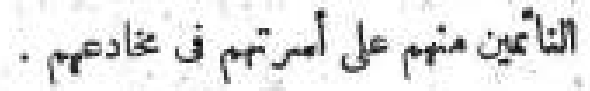

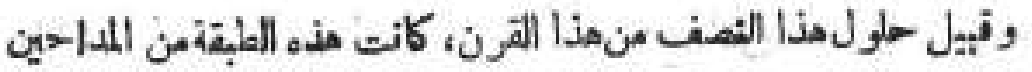

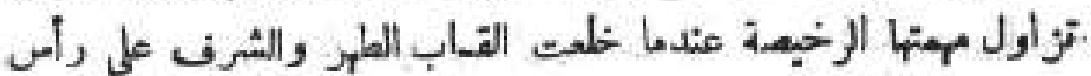

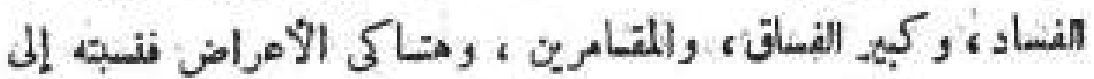
اليت الثبوى الثريف . 
$$
\text { - \&1- }
$$

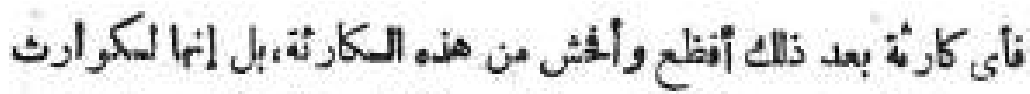

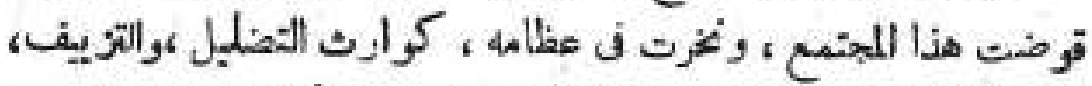

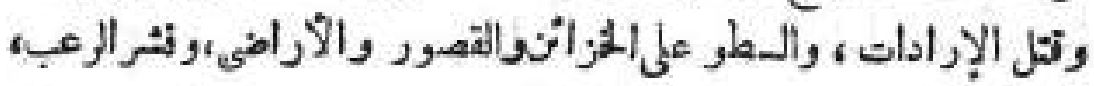
والقزع ، باستمال البطث ، والفتل والتجويع •

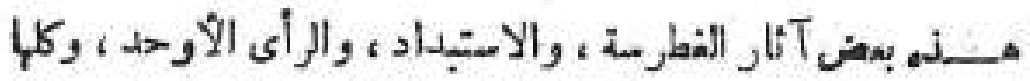

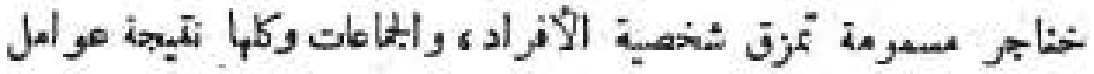

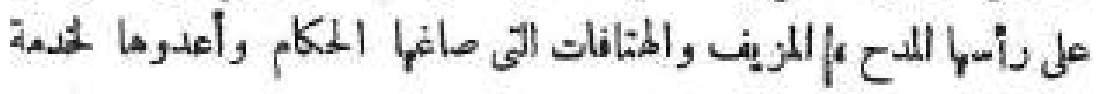
11 مer

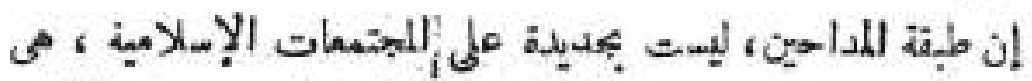

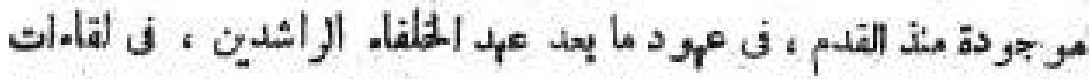

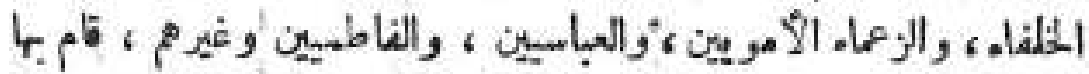

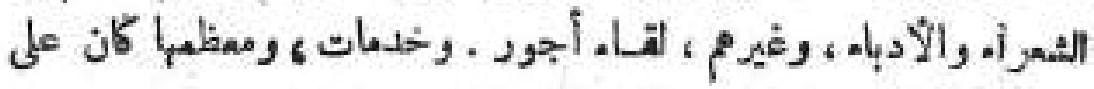

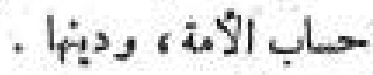

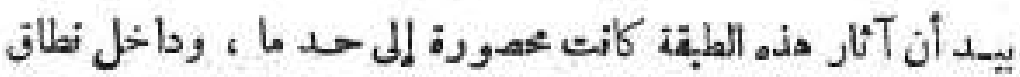

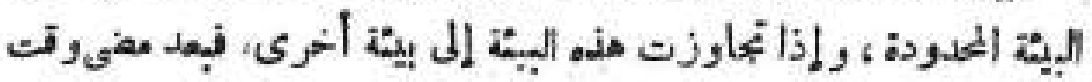

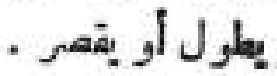

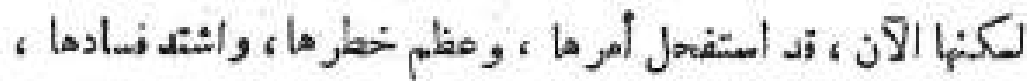

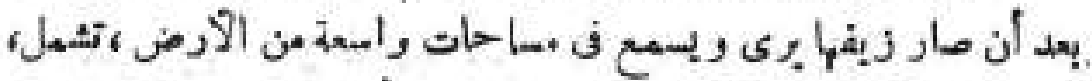

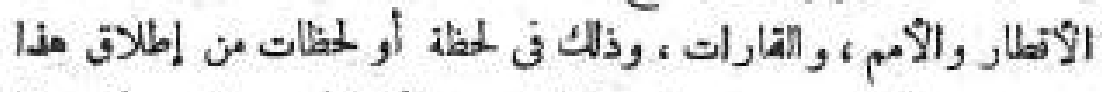

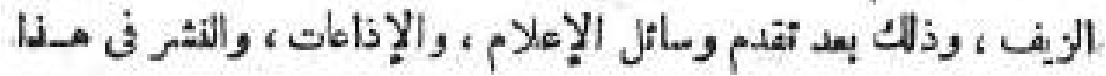

- العصري

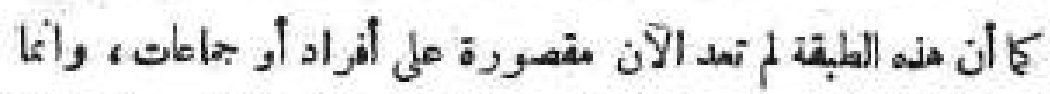

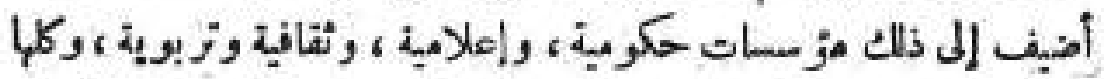

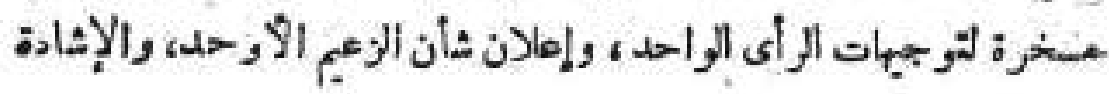




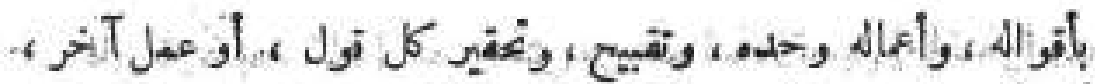

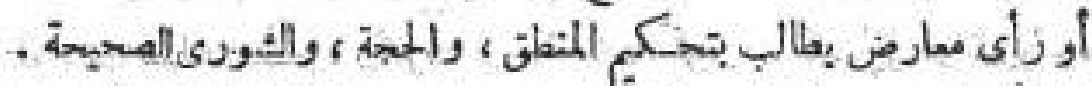

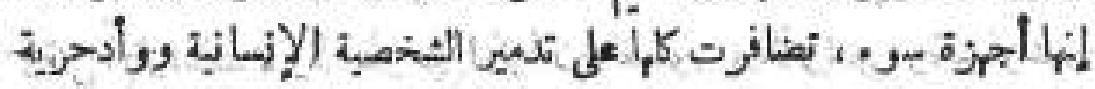

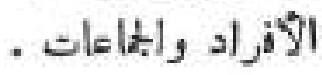

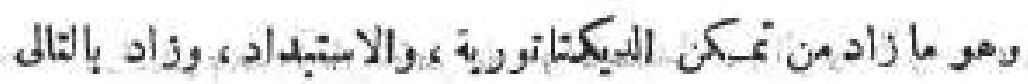

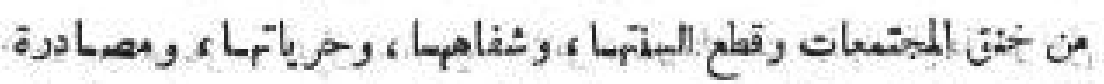

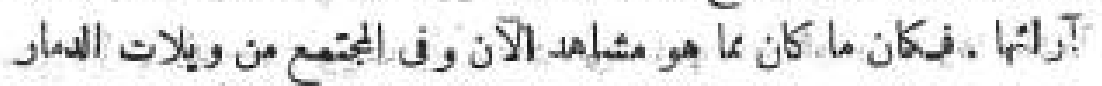

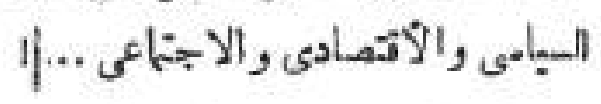

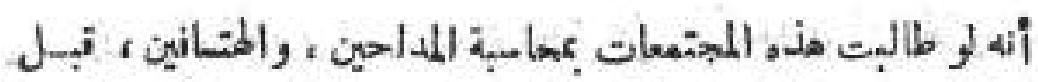

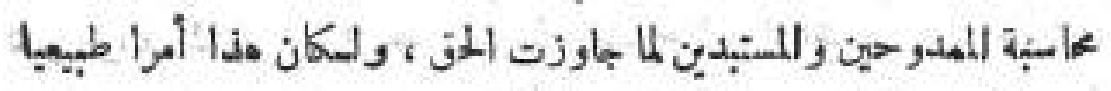

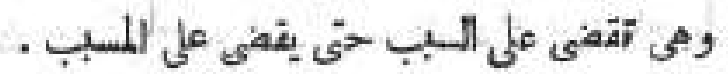

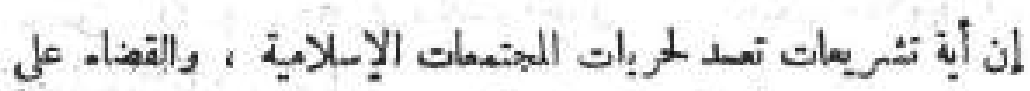

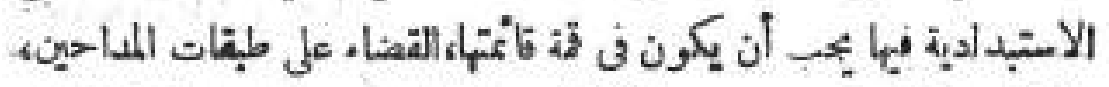

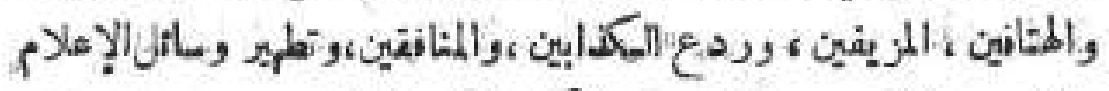

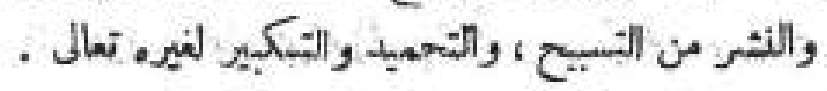

$$
\text { - }
$$

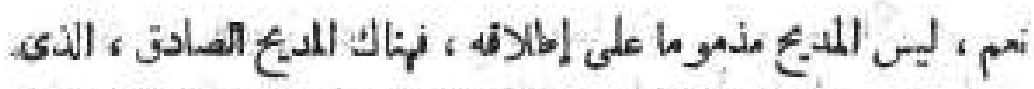

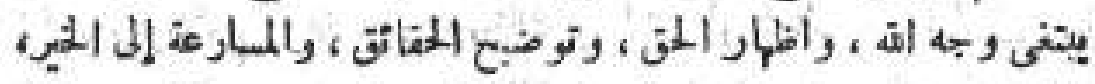

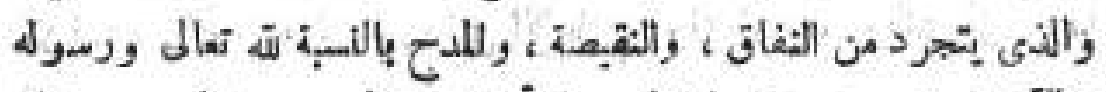

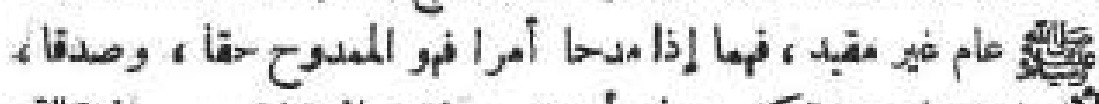

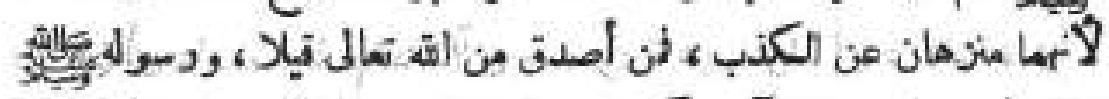

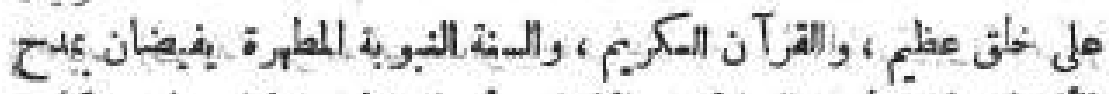

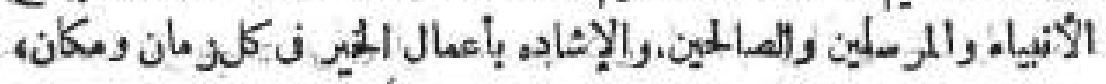




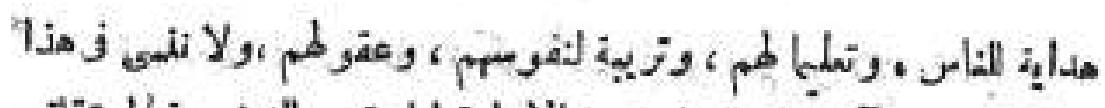

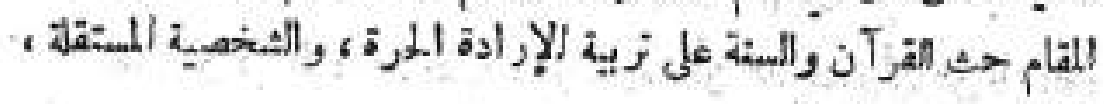

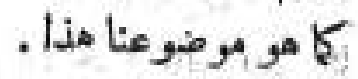

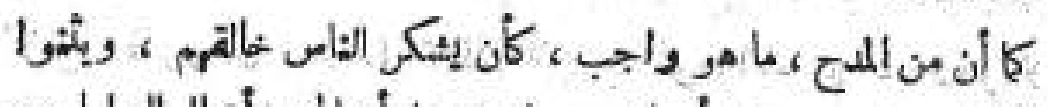

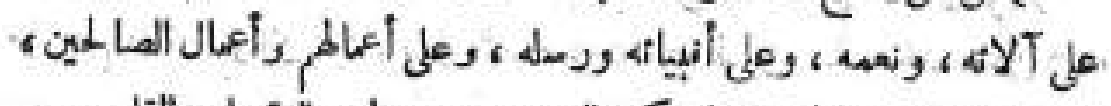

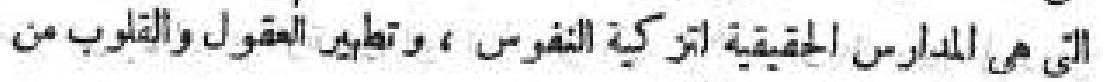

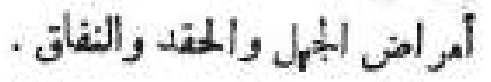

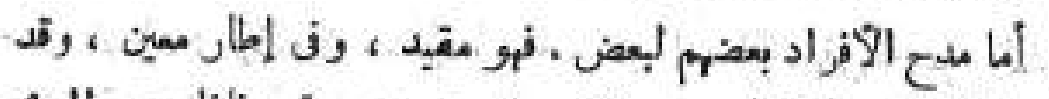

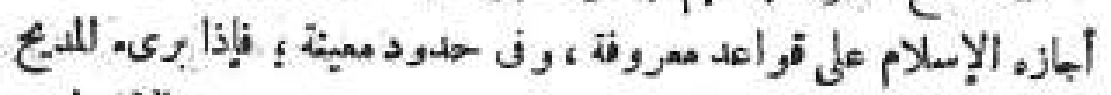

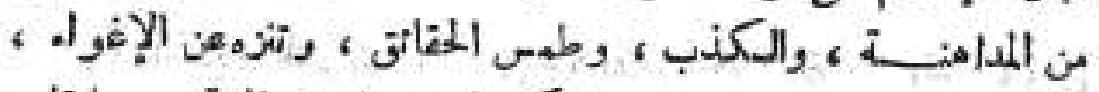

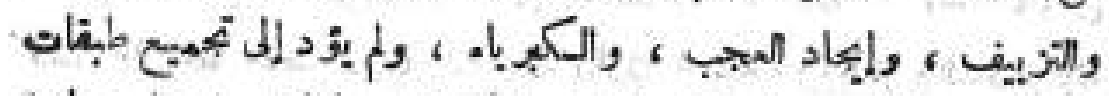

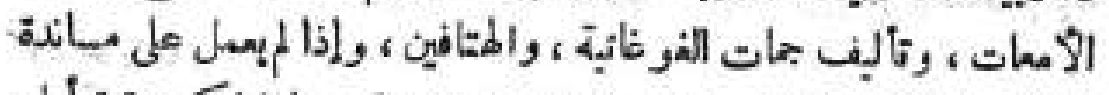

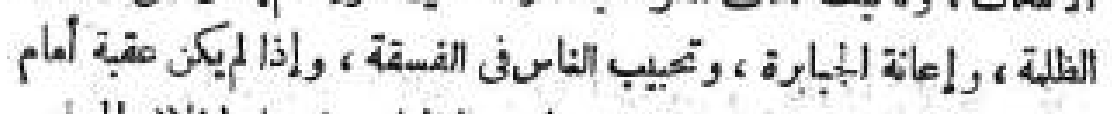

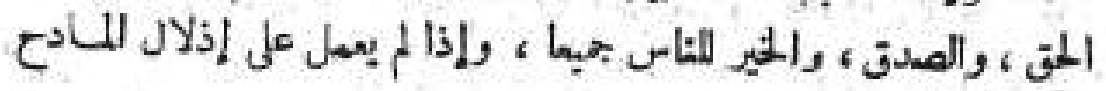

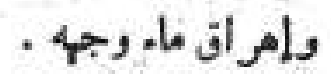

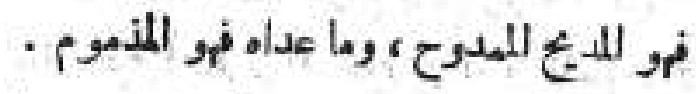

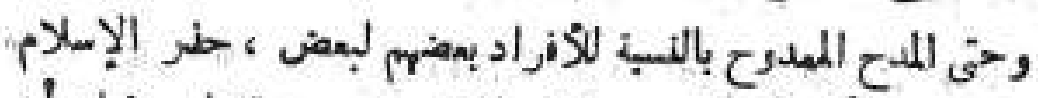

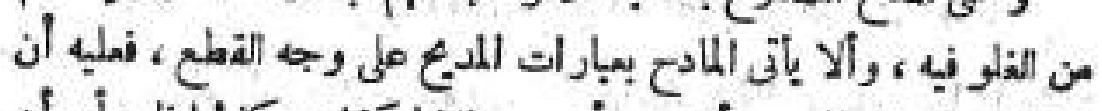

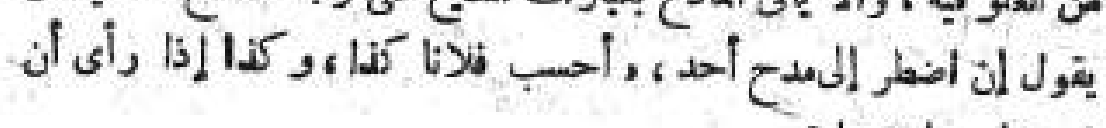

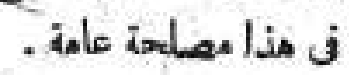

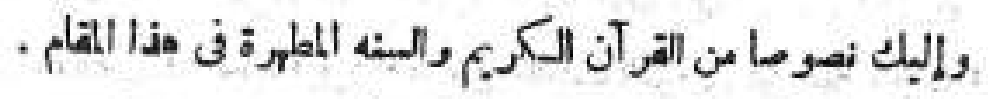

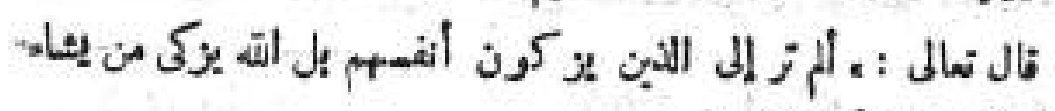

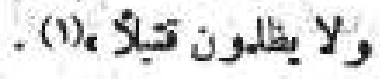

(1) (1) 


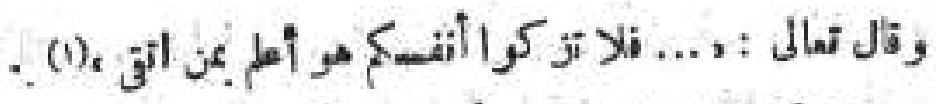

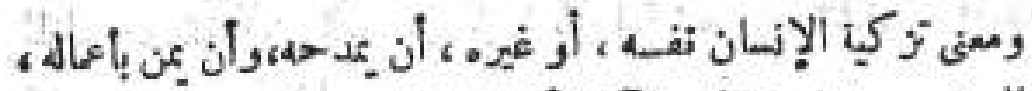

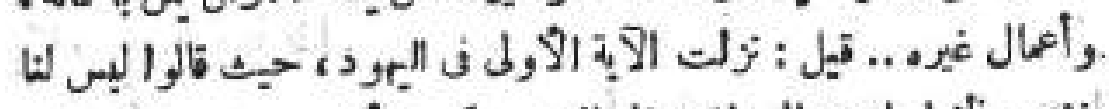

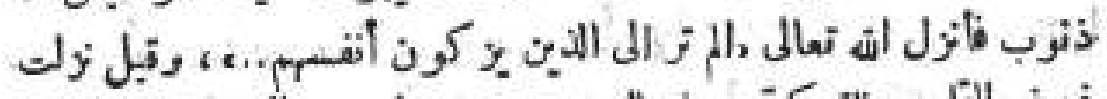

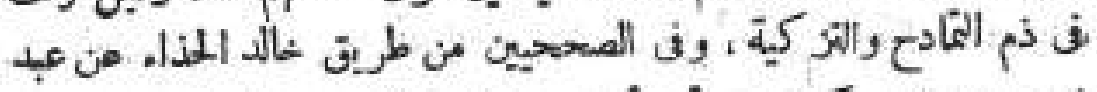

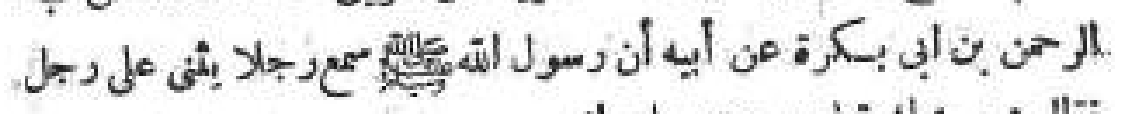

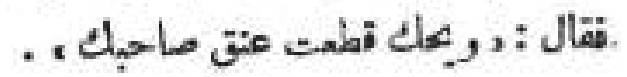

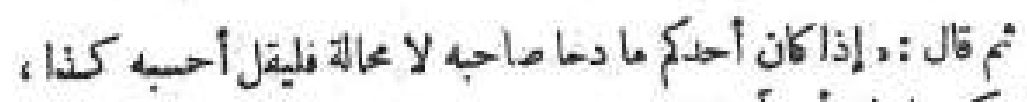

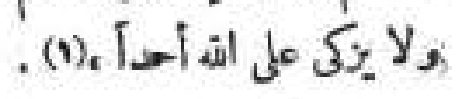

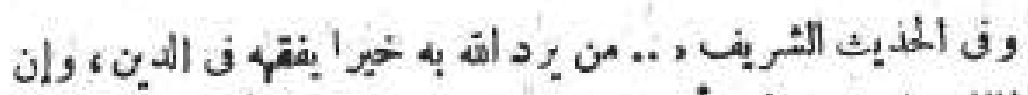

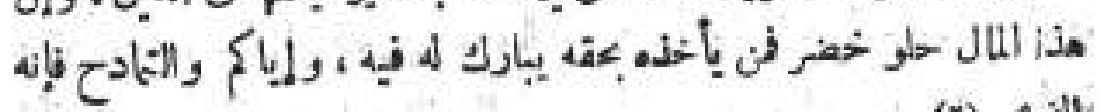

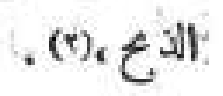

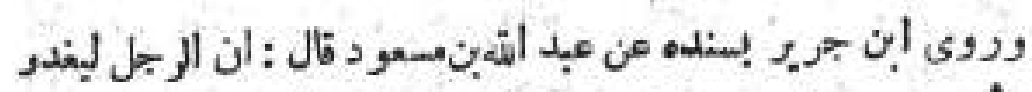

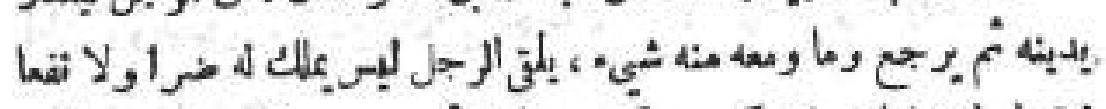

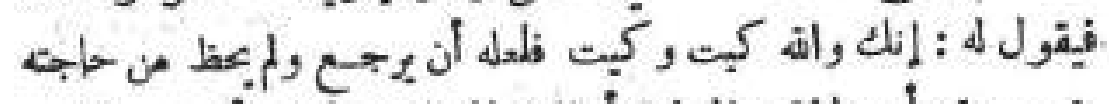

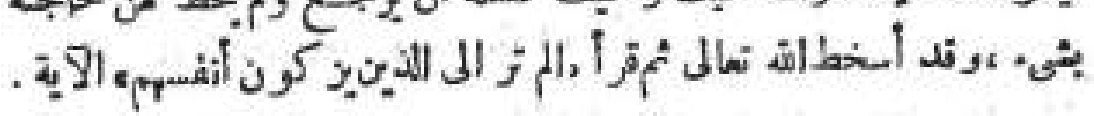

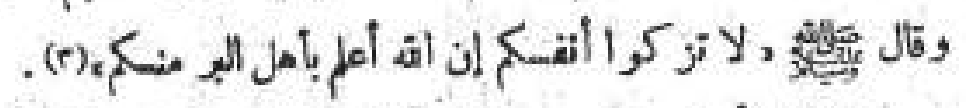

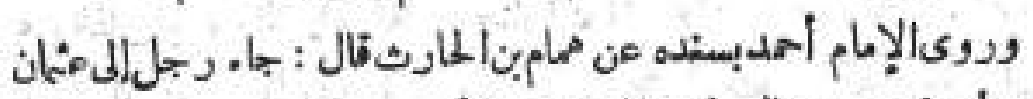

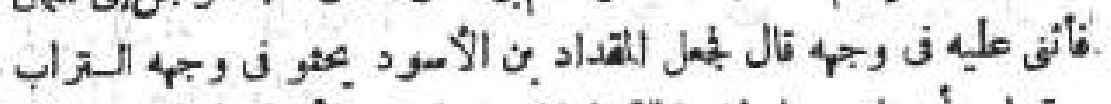

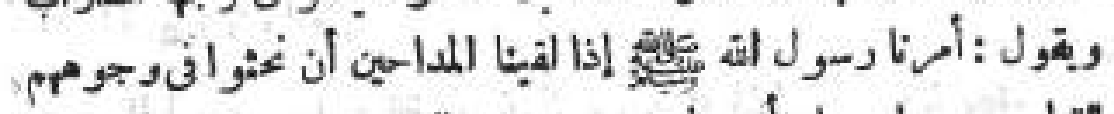

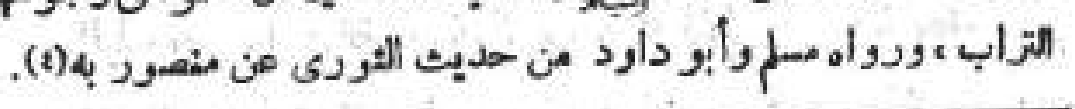

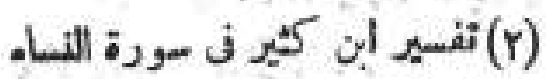
rr الثبح (1)

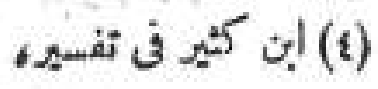
(r) المصدر السابت (0) المصدو السابق الماتق 


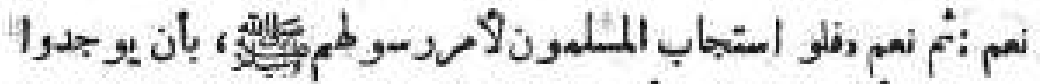

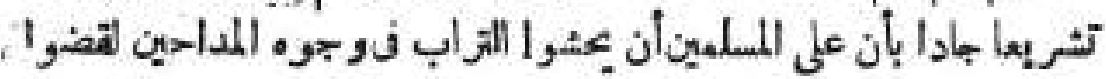
بذالك التشربع على طبقات المفهيين، والوصو ليبين والمداهنين ، والمتافين ..

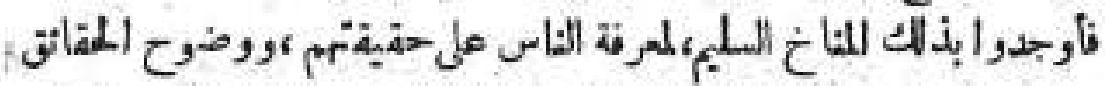

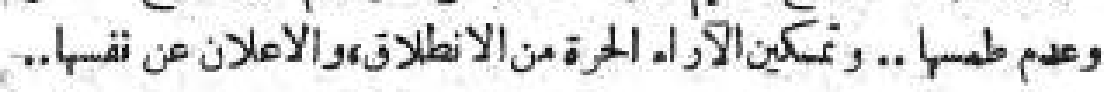

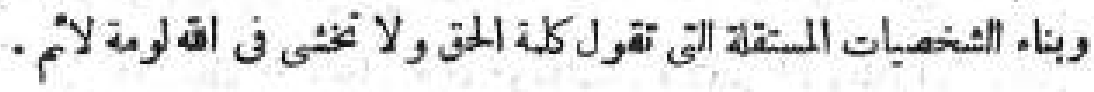
:

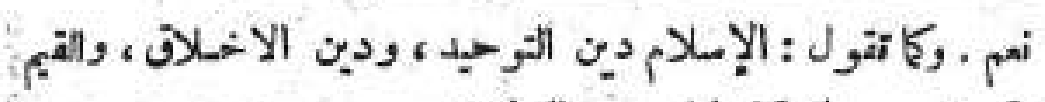

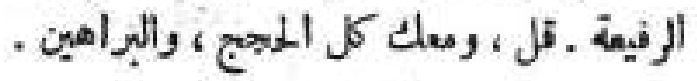

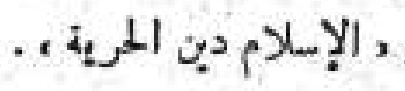

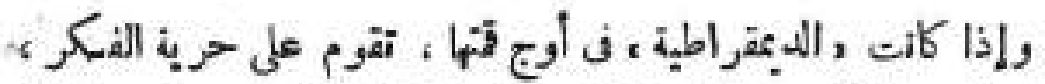

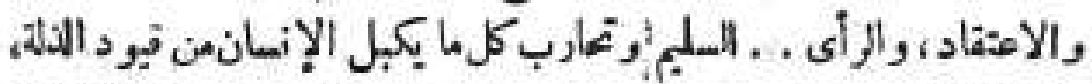

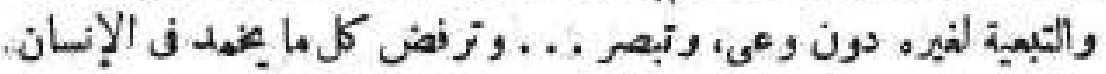

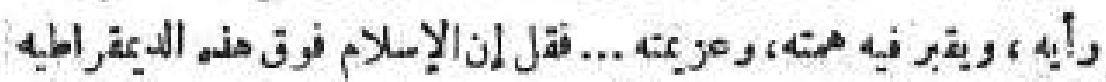

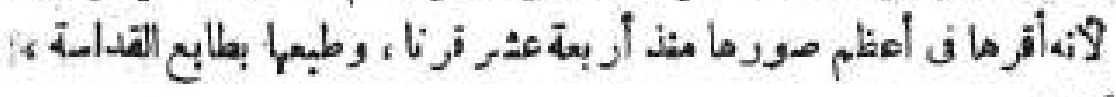

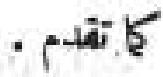

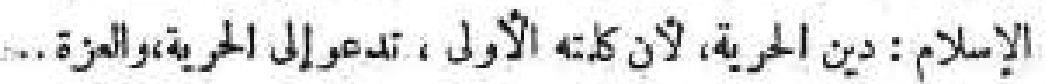

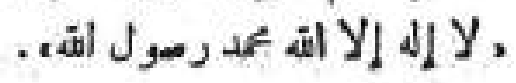

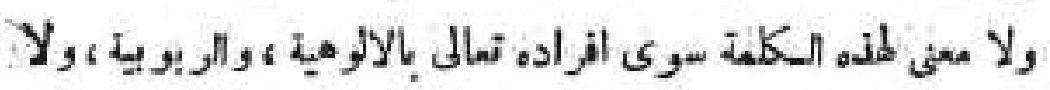

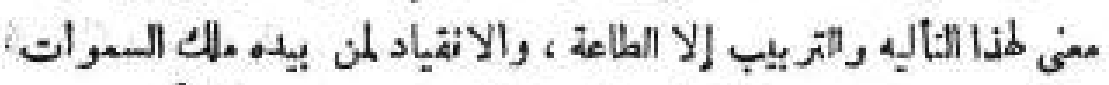

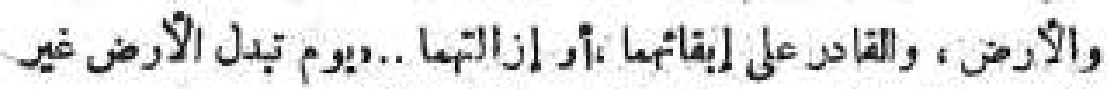

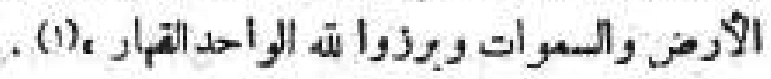




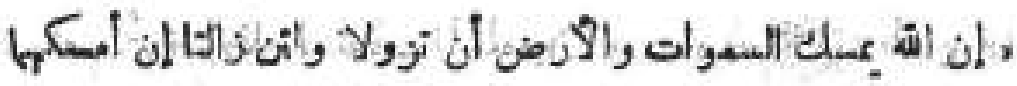

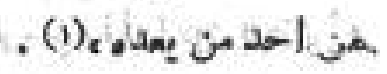

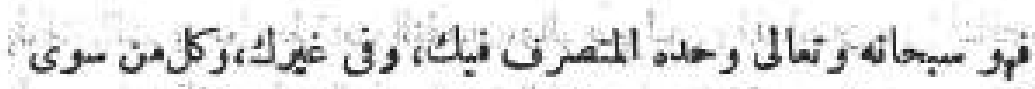

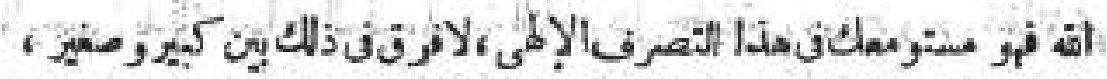

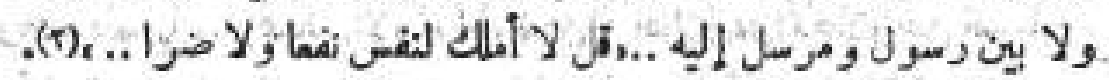

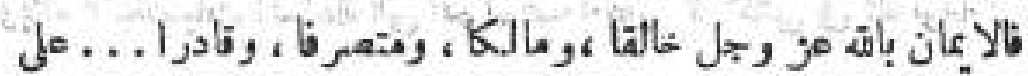

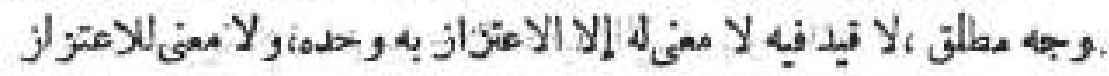

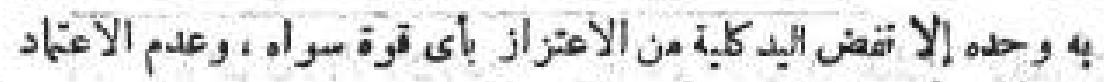

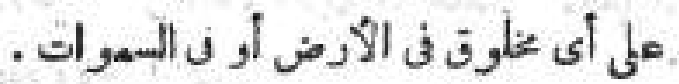

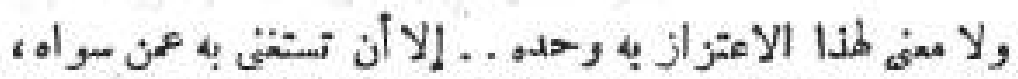

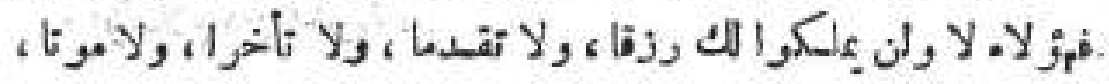
ولا عياة.

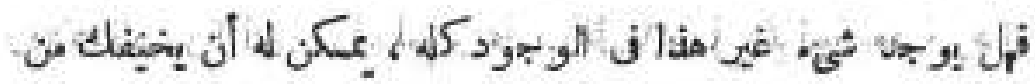

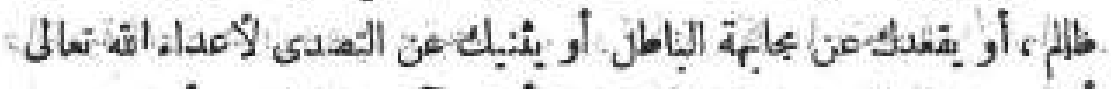

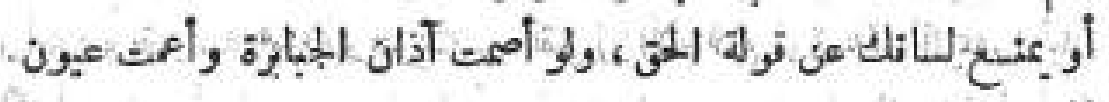
إلمتبدين.

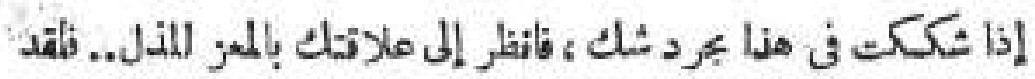

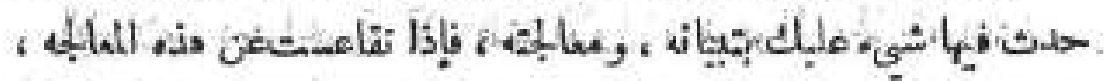

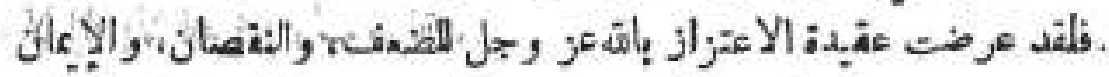

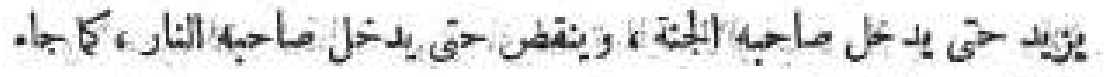

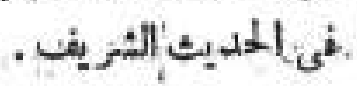

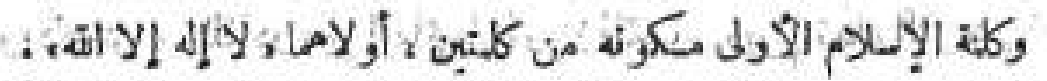

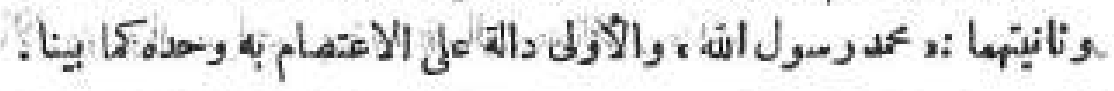

$$
\text { MA الإعراف }
$$$$
\text { \& (؟) }
$$ 


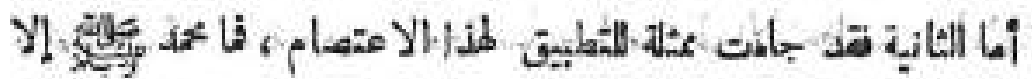

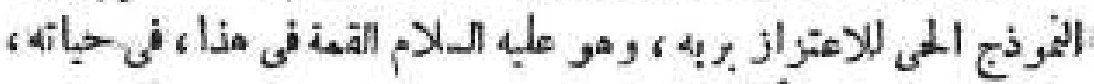

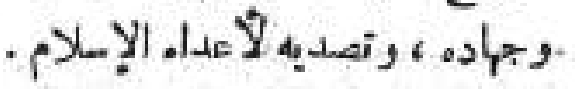

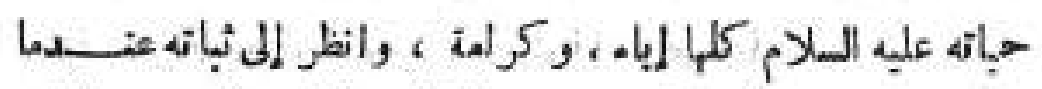

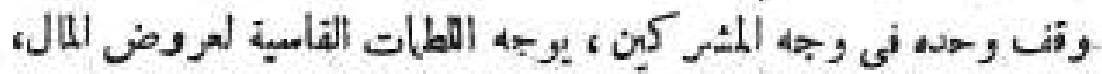

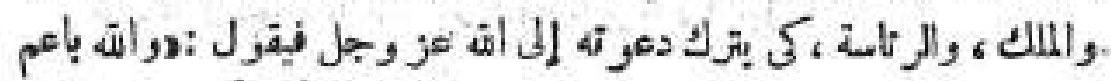

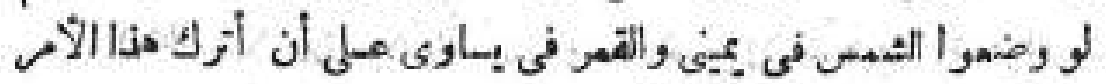

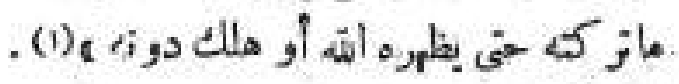

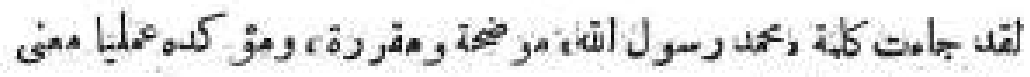

$$
\text { الاعتزار بواهب المهياة . }
$$

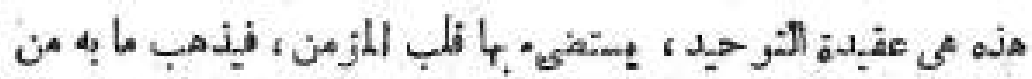

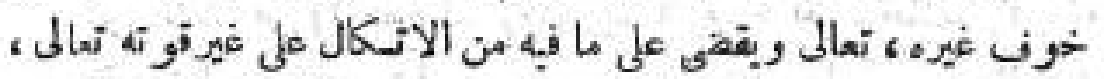

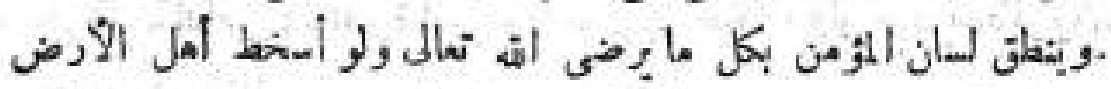

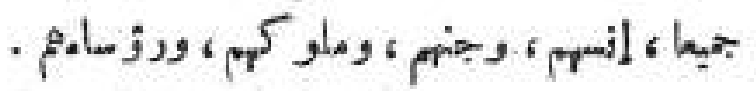

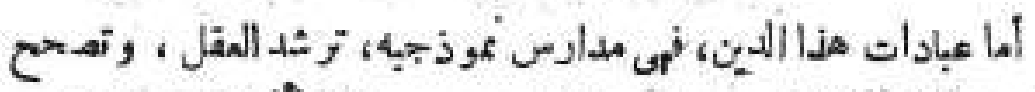

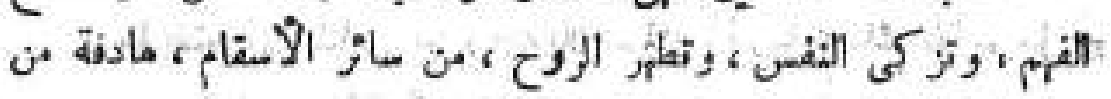

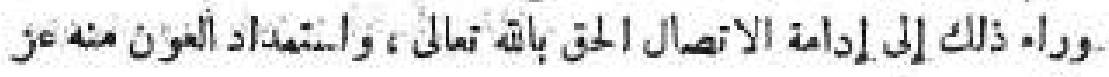
ثأه.

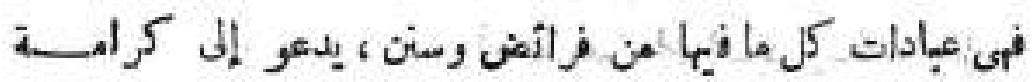

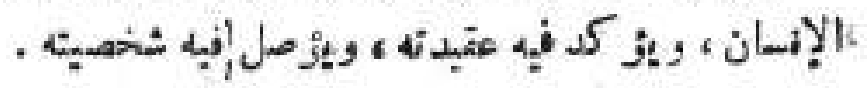

فالهـاذة مثلا جاءت في الإسلام على صورة تعتق هذا الهدف ، لقد

$$
\text { (1) - (1) إيرة هثام }
$$




\section{$-\varepsilon N-$}

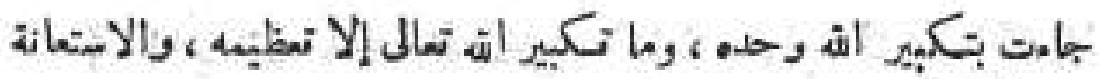
$\therefore$. ole

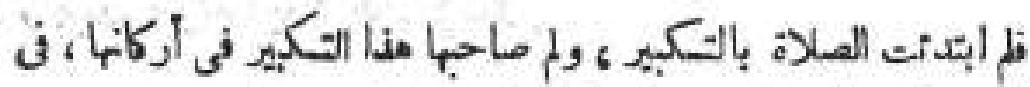

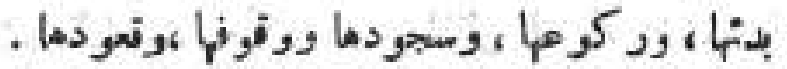
لم تـكرد فيها هذا التككير ، والتحميد، والتهليل . ولم كانت لا تشعد إلا بالتـكير ، ولا تصح إلا بتكبيرة الإحرام. ولم كان الأذان اللصلاة فى اليوم والليلة تحس مرات، مشتملا على

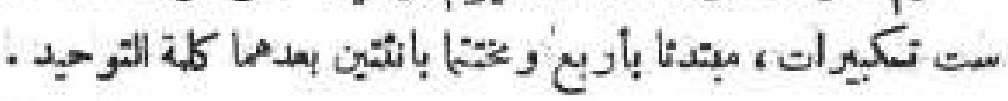
هل لذلك معنى إلا إيكاد المسلم العزيز .

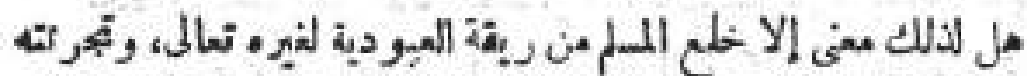

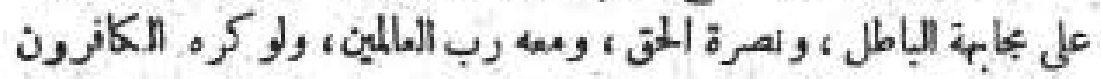
والألالمون الطفاة .

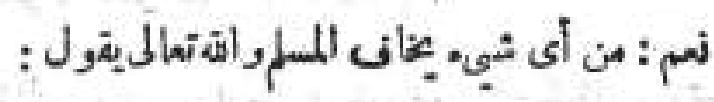

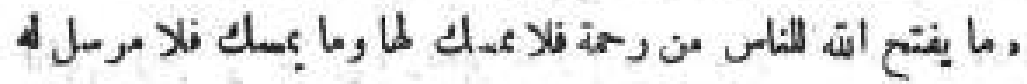

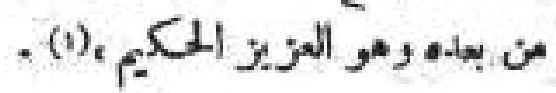

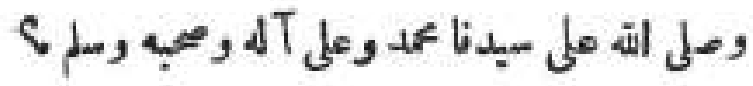

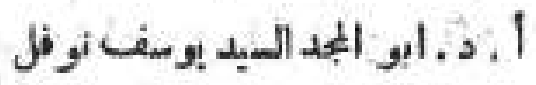

